\title{
DOES THE INSURANCE SECTOR REALLY MATTER FOR ECONOMIC GROWTH? EVIDENCE FROM CENTRAL AND EASTERN EUROPEAN COUNTRIES
}

\author{
Yilmaz BAYAR (D) ${ }^{1}$, Marius DAN GAVRILETEA (D2*, \\ Dan Constantin DANULETIU (D) 3 \\ ${ }^{1}$ Department of Public Finance, Faculty of Economics and Administrative Sciences, \\ Bandirma Onyedi Eylül University, Bandirma-Balıkesir, Turkey \\ ${ }^{2}$ Business Department, Faculty of Business, Babeş-Bolyai University, Cluj-Napoca, Romania \\ ${ }^{3}$ Department of Finance-Accounting, Faculty of Economic Sciences, \\ 1 Decembrie 1918 University, Alba Iulia, Romania
}

Received 11 December 2019; accepted 04 December 2020

\begin{abstract}
This paper analyses the impact of insurance sector development on economic growth based on a sample that includes 14 Central and Eastern European (CEE) post-transition countries for a period of 19 years, from 1998 to 2016. Considering the presence of cross-section dependence and multiple structural breaks, recently developed panel econometric techniques were employed and led to the following conclusions: (1) life insurance has no significant effect on economic growth in both panel and individual countries, (2) non-life insurance positively affects economic growth in both panel and individual countries, (3) Dumitrescu and Hurlin causality test indicates a unidirectional causality running from economic growth to both life and non-life insurance and infers the absence of causal connection between life and non-life insurance and economic growth.
\end{abstract}

Keywords: insurance sector, life insurance penetration, non-life insurance penetration, economic growth, Central and Eastern Europe, multiple structural breaks, panel cointegration, causality.

JEL Classification: G22, O40, C33.

\section{Introduction}

There are many factors that stimulate economic growth and among them, the financial development is considered a vital component of economic development. The influential role of a well-developed financial system in supporting economic development is not new: Bagehot (1873), Schumpeter (1911, 1912/1934), Gurley and Shaw (1955), Hicks (1969) were among the first authors that emphasized the importance of finance in economic development. More recently, many studies explored the influence of financial development on economic growth

*Corresponding author. E-mail: marius.gavriletea@ubbcluj.ro

Copyright (c) 2021 The Author(s). Published by Vilnius Gediminas Technical University

This is an Open Access article distributed under the terms of the Creative Commons Attribution License (http://creativecommons. org/licenses/by/4.0/), which permits unrestricted use, distribution, and reproduction in any medium, provided the original author and source are credited. 
considering different countries, periods of time, variables, and procedures and reported mixed results.

There exists a general agreement between researchers related to the correlation between finance and growth, but divergent views were noticed related to the direction of causality.

Authors like Rioja and Valev (2004), Christopoulos and Tsionas (2004), Bittencourt (2012), Uddin et al. (2013), Pradhan et al. (2016), Durusu-Ciftci et al. (2017), Guru and Yadav (2019), Sulemana and Dramani (2020), have underlined that the development of the financial sector can influence in a positive manner economic growth, but other studies conducted by Ram (1999), Ang and McKibbin (2007), Adusei (2013), Mmolainyane and Ahmed (2015) have found a negative relationship.

Considering that a large body of empirical studies found that a well-performed financial sector exerts a positive effect on economic growth, we assume that insurance companies along with banks and other financial institutions play an essential role as a driving force of economic development (United Nations, 1964) through risk protection and strengthening financial intermediation.

Banks and stock markets are considered, in many studies, the most important determinants of economic growth (Levine \& Zervos, 1998; Liang \& Reichert, 2006, 2012; Petros, 2012; Zortuk \& Çelik, 2014; Raza \& Jawaid, 2014; Ahmed \& Bashir, 2016; Abusharbeh, 2017; Tongurai \& Vithessonthi, 2018; Jayakumar et al., 2018; Bayar \& Gavriletea, 2018; Ledhem \& Mekidiche, 2020; Bayar et al., 2020) and the relationship insurance-economic growth is not frequently debated. However, by managing risks and providing protection for individuals and companies, the insurance sector exerts an active role in countries' economic and financial development. It is estimated that the global insurance market will reach EUR 7.9 trillion in 2030 (Munich Re, 2018).

Insurance provides protection but at the same time it can promote economic development (Skipper, 2001) in different ways: it ensures financial stability among households and firms, mobilizes savings and channels them to other sectors, stimulates international trade relations and commerce, encourages entrepreneurship and additional investment and consumption, acts as a social protection mechanism, fosters capital accumulation and improves resource allocation (Outreville, 2013; Ricci, 2014).

The development of insurance markets is closely associated with the macroeconomic factors, regulatory and supervisory practices that govern this specific sector, as well as the global trade regime (United Nations, 2007).

Insurance is considered an important component of advanced economies (Cristea et al., 2014) where insurance spending represents approximately $8-11 \%$ compared to $2-4 \%$ in developing countries (Din et al., 2017). According to Kessler et al. (2016), low levels of economic development generate low insurance penetration. Therefore, even if the insurance sector has grown in importance in recent years, insurance penetration remains relatively low in developing countries. Limited access and cost can be barriers for accessing insurance coverage in this category of countries and governments need to find and promote solutions and also to educate people to support development in this sector.

The CEE countries have undergone structural and economic transformations with the fall of communism. In this context, the countries become more integrated with the global 
economy and have experienced gradual improvements in the financial system. We must underline that financial development differs considerably across these countries (Caporale et al., 2015; Anton, 2019). The study of Caporale et al. (2015) emphasizes that the financial sector in CEE countries is more developed compared to the one in the Southeastern European and Baltic countries (Bulgaria, Romania, Estonia, Latvia, and Lithuania).

Even these countries experienced a similar economic system, after the fall of communism economic development levels evolved differently over time. Large differences are noticed among these countries in terms of income inequality or economic performance (Anton, 2019). Transformation of centrally planned economies into market-oriented economies started in the early 1990s and implied significant changes in all economic sectors. Financial sector has undergone profound and continuous changes, the greater emphasis being placed especially on the transformation of the monobank system to one with multi-financial institutions.

This study attempts to provide new reliable evidence for a causal link between the insurance market and economic development using a panel of 14 CEE countries over the period 1998-2016.

In the related literature, evidence for insurance growth nexus was found for different samples including various CEE countries in studies conducted by Curak et al. (2009), Njegomir and Stojic (2010), Pradhan et al. (2017), Peleckienè et al. (2019), and Wanat et al. (2019). Meanwhile, Njegomir, and Stojic (2010) and Curak et al. (2009) that have employed regression analysis, and Pradhan et al. (2017), Peleckienè et al. (2019) and Wanat et al. (2019) that have used causality analysis.

Unlike other studies that have not employed econometric tests regarding structural breaks, we took into consideration the evidence of structural breaks and we used a recent technique developed by Carrión-i-Silvestre et al. (2005) and the method proposed by Basher and Westerlund (2009). Consequently, our paper is evaluated to make a contribution to the relevant literature in terms of methodological approach, to give more reliable results.

The remainder of this paper is divided as follows: Section 1 summarizes the earlier studies, Section 2 describes the data and research methodology applied in our research, Section 3 discusses the main empirical findings obtained from panel data analysis and finally, last Section introduces the main conclusions.

\section{Scientific literature review}

Many articles have dealt with finance-growth nexus, but most of them have concentrated on the banking system and/or stock markets. Despite the fact that, at the first UNCTAD held in 1964, it was highlighted that a developed insurance market is an important tool for achieving economic growth, the first papers that empirically analyzed the connection appeared just in the 80 's.

There are no direct measures of insurance development, therefore its impact on economic growth must rely on several proxies: total insurance premiums, insurance density, insurance penetration, and property liability insurance premiums.

Researchers like Ward and Zurbruegg (2000), Adams et al. (2005) used total the insurance premiums as a proxy for insurance market. 
Ward and Zurbruegg (2000) investigated for the period between 1961 and 1996 the causality between insurance and economic development in the case of 9 OECD countries. Their results show that for some countries (Canada, Japan) insurance sector development generates potential for economic growth. Meanwhile, for other countries (like USA, UK, Switzerland, and Austria) no insurance-economic growth relationship has been found and for Italy the existence of a bidirectional relationship has been confirmed. They suggest that the structure of the insurance market, having two main components (non-life and life), could affect insurance-economic growth relationship and raised questions about others factors (cultural factors, legal and regulatory environment or models of financial intermediation) that could influence this relationship.

Causal linkage between banking and insurance sector and economic growth was analyzed by Adams et al. (2005) for Sweden and findings indicate that development of insurance is driven by economic growth, rather than an inverse relationship.

Other studies used net written premium as a measure of insurance industry development.

In this context, based on a single country analyses, Kugler and Ofoghi (2005) investigated the short and long-run relationships existing between insurance market size and economic growth and pointed out that the analyzed relationship is positive in the UK.

Njegomir and Stojic (2010) research included five countries that constituted the former Yugoslavia and it indicated that insurance has a positive influence as a risk provider, but also as an institutional investor on economic growth.

Using property liability insurance premiums to measure insurance activity, Beenstock et al. (1988) analyzed data from 12 countries over the 1970-1981 period and discovered that incomes positively influence insurance consumption. Outreville (1990) reached the same results for non-life insurance.

In recent years, many studies used insurance density as an indicator that provides information about the importance of the insurance sector on the development of a national economy.

In this context, Han et al. (2010) tested the insurance-growth relationship for 77 economies (split into developed and developing ones) for the 1994-2005 period by employing GMM models. Analyzing the full sample of countries, they found that total insurance, but also life and non-life components, influence in a positive manner economic growth. Their findings also suggest that non-life insurance's influence is higher than that of life insurance. By splitting the countries into two samples (developed and developing countries), they highlighted that there are some differences that appear between these two categories of countries: for the developed ones, only the total insurance and the nonlife component have an incidence on economic growth, but for the developing ones, all three categories of insurance influence growth.

Su et al. (2013) analyzed life and non-life insurance development relations with economic growth in seven countries from Middle East. Their results asserted that country-specific factors affect the relationship, especially for life insurance. Moreover, the authors identified, for high-income economies, a bidirectional life insurance market - economic growth causal relationship, while the findings for low-income countries report a unidirectional causal linkage running from non-life insurance to economic growth. 
Demirci and Zeren (2017) investigated 13 OECD countries for the 1983-2011 period and confirmed the existence of a unidirectional causal relationship between insurance and economic growth for Iceland, Italy, France and Spain.

Pradhan et al. (2017) analyzed insurance-growth nexus for 19 Eurozone countries for the 1980-2014 period. Mixed results were noticed, supporting all four hypotheses: demandfollowing hypothesis (economic growth promotes insurance), supply-leading hypothesis (insurance leads to growth), feedback hypothesis (bidirectional causality insurance - growth), and neutrality hypothesis (no causal relationship).

Using a sample of 10 transition EU countries, Wanat et al. (2019) analyzed the causal linkage between insurance market and economic development for the 1993-2013 period. The results for Romania and Slovakia (for life insurance) and for Estonia and Slovakia (for total insurance) support the supply leading hypothesis. The demand following hypothesis found support in Romania (for non-life and for total insurance), and also in Hungary and Poland (for non-life insurance) and in Bulgaria (for total insurance). The results reported for Czech Republic, Latvia, Lithuania, and Slovenia for all three cases (total, life and nonlife insurance), for Bulgaria (for life and non-life insurance), for Hungary and Poland (for life and total insurance) and for Estonia (non-life insurance) suggest that there is no causal relationship between insurance and growth. Feed-back hypothesis found support for Estonia (for life insurance) and for Slovakia (for non-life insurance).

Another important indicator used as a proxy for insurance development is insurance penetration.

By assessing GMM method, Arena (2008) tested the causal relationship between both insurance sectors (life and non-life) and economic growth using a panel of 55 countries in the period between 1976 and 2004 and found that both sectors influence economic growth significantly and the impact differs based on a country's level of development.

Using information from 10 European Union (EU) transition countries over the 19922007 period, Curak et al. (2009) investigated insurance - economic growth nexus by applying the fixed-effects panel model and found that economic growth is affected in a positive and significantly way by life, non-life and aggregate insurance.

Guochen and Wei (2012) investigated the insurance - growth relationship for 31 regions of China using insurance penetration for life and non-life components as dependent variables. They found arguments for the importance of the level of income as a factor of influence in this relationship. Their findings indicated that, in high income regions, economic growth leads to life and non-life insurance development, while for the other regions, characterized by different developing stages, the insurance sector development leads to economic growth.

Alhassan and Biekpe (2016) studied the insurance (measured by insurance penetration) growth relationship for eight African nations and identified that a long-run insurance - economic growth relationship exists for five of these countries. One-way causality from insurance to economic growth was noticed in six countries. A reverse one-way causal relationship from economic growth to insurance was reported for Gabon, and bidirectional causality was found in Morocco.

Peleckienè et al. (2019) analyzed insurance (measured by penetration) - economic growth relationship in a study that used data from European Insurance Federation members over the period of 2004-2015. The supply-leading hypothesis is supported in 3 countries: Nether- 
lands, Malta and Estonia. The demand-following causality pattern was noticed in countries like Luxembourg and Finland. A bidirectional causality was found in Austria and no causal relation was reported in Slovakia.

Balcilar et al. (2019) examined the causal relationship between insurance (as reflected by penetration of total insurance or of its components) and economic growth, using a panel of 11 African countries for the period 1995-2016, and identified a long-term impact of both non-life and life insurance on growth, but also a bidirectional causal linkage between total insurance and growth. In the same time, they highlight that the non-life effect on growth is higher than the effect of life insurance.

Other studies used mixed variables for insurance market development.

Insurance premiums and total net investments of insurance were used as variables by Haiss and Sumegi (2008) to measure, for the 1992-2005 period, the insurance demand in a panel of 29 European countries. Results indicated that life insurance acted positively on economic growth for 15 European matured economies. Meanwhile, the results found that between the expenditures for insurance and GDP exists a short-run relationship in the case of transition countries.

Analyzing a sample of 20 developed and developing countries for the years between 2008 and 2015, Din et al. (2017) tested the influence of non-life and life insurance over the economic growth for both categories of countries. Three proxies were used for insurance development (net written premiums, penetration, and density) and the results differ depending on which proxy was used for analyses. Non-life insurance was found to be important for economic growth in the developing countries, but for the other group of countries (the developed ones), this is true just when the indicator used is insurance density. As for life insurance, the influence for developed countries is positive and significant when net written premiums or insurance density are used, but for the developing countries this effect is detectable when penetration is used. Their study indicates that the level of the countries' development is important for the insurance-growth relationship.

Based on our literature review, we can notice more patterns in the causal relationship between insurance development and economic growth: demand-following pattern (Han et al., 2010; Guochen \& Wei, 2012; Alhassan \& Biekpe, 2016; Peleckienè et al., 2019); supplyleading pattern (Haiss \& Sumegi, 2008; Peleckienè et al., 2019), feedback pattern (Ward \& Zurbruegg, 2000; Kugler \& Ofoghi, 2005; Guochen \& Wei, 2012; Alhassan \& Biekpe, 2016; Peleckienè et al., 2019; Balcilar et al., 2019); neutrality - lack of causality between variables (Guochen \& Wei, 2012; Peleckienè et al. 2019).

As a conclusion, after the study of Ward and Zurbruegg (2000), the empirical literature on the insurance-economic growth nexus was developed in various ways: by dividing total insurance into components, by analyzing different countries or groups of countries in order to identify the importance of some specific factors for this relationship, by testing for the interactions between insurance and other financial intermediaries in the causal relationship with economic growth, by using different indicators for insurance market development, etc. Despite this growing body of literature attempting to explore the nature of causality between the development of insurance markets and economic growth, a consensus was not found at this moment, therefore further research is needed. 


\section{Research methodology}

\subsection{Data}

An empirical study was conducted using data from 1998 to 2016 for 14 post-transition CEE economies. Countries were selected based on data availability: Czech Republic, Slovak Republic, Poland, Lithuania, Latvia, Estonia, Croatia, Serbia, Slovenia, North Macedonia, Bosnia and Herzegovina, Bulgaria, Hungary, and Albania. Montenegro and Romania are not included in the sample due to a non-availability of relevant data. Econometric analysis was performed using Eviews 10, Stata 14.0, and Gauss 10.0 software packages.

The variables incorporated in our applied section are described in Table 1: growth rate was employed to capture economic development (GRW), life insurance penetration (LIFEINS), and non-life insurance penetration (NON-LIFE) were used to measure insurance sector developmet. We used the insurance penetration rate for our research based on the International Association of Insurance Supervisors consideration, indicated that this indicator is "the most conventional tool used to gauge the development of a country's insurance market” (International Association of Insurance Supervisors, 2017).

Table 1. Description of variables (source: own processing)

\begin{tabular}{|l|l|c|}
\hline \multicolumn{1}{|c|}{ Symbol } & \multicolumn{1}{c|}{ Variables } & \multicolumn{1}{c|}{ Source } \\
\hline GRW & Growth rate of real GDP per capita (annual \%) & World Bank (2019a) \\
\hline LIFEINS & Life insurance penetration & World Bank (2019b) \\
\hline NON-LIFE & Non-life insurance penetration & World Bank (2019c) \\
\hline
\end{tabular}

The following empirical model was developed to research the growth effect (GRW) of the insurance sector represented by LIFEINS and NON-LIFE in country $i(i=1, \ldots, 14)$ in year $t(t=1998, . ., 2016)$.

$$
G R W_{i t}=f\left(\text { LIFEINS }_{i t}, N O N-L I F E_{i t}\right) .
$$

We expect that insurance sector development will stimulate economic growth, according to the findings of Beenstock et al. (1986), Arena (2008), Njegomir and Stojić (2010).

Summary statistics of the series employed in our research are displayed in Table 2. A positive association between the insurance sector indicators and economic growth was confirmed. Furthermore, the mean of life insurance in the sample as a percent of GDP was about $0.67 \%$ and the mean of non-life insurance as a percent of GDP was about $1.47 \%$, so non-life insurance size was higher than the life insurance sector in the sample.

Table 2. Descriptive statistics (source: own processing)

\begin{tabular}{|l|c|c|c|}
\hline & GRW & LIFEINS & NON-LIFE \\
\hline Mean & 3.344865 & 0.679087 & 1.476548 \\
\hline Median & 3.833986 & 0.430000 & 1.475000 \\
\hline Maximum & 15.60000 & 2.710000 & 2.850000 \\
\hline
\end{tabular}


End of Table 2

\begin{tabular}{|l|c|c|c|}
\hline & GRW & LIFEINS & NON-LIFE \\
\hline Minimum & -14.81416 & 0.000000 & 0.360000 \\
\hline Std. Dev. & 4.142074 & 0.597956 & 0.474747 \\
\hline \multicolumn{4}{|c|}{ Correlation matrix } \\
\hline & GRW & LIFEINS & NON-LIFE \\
\hline GRW & 1.000000 & 0.131833 & 0.130217 \\
\hline LIFEINS & & 1.000000 & 0.347872 \\
\hline NON-LIFE & & & 1.000000 \\
\hline
\end{tabular}

\subsection{Econometric methodology}

The cross-sectional dependence among the series was questioned using Breusch-Pagan LM test (Breusch \& Pagan, 1980), Pesaran (2004) CD test, and LM adjusted test of Pesaran et al. (2008), then the cointegration coefficients' homogeneity was explored by applying Pesaran and Yamagata (2008) test.

Taking notice of cross-sectional dependence and multiple structural breaks, we've investigated the integration level of the series using the second generation of unit root and cointegration tests. The panel unit root test developed by Carrión-i-Silvestre et al. (2005) was employed to examine the variables' stationarity and Basher and Westerlund (2009) cointegration test was used to test the existence of a long-run relationship.

After the cointegration relation was confirmed, long-term coefficients were estimated based on Fully Modified Ordinary Least Square (FMOLS) method. Lastly, the procedure proposed by Dumitrescu and Hurlin (2012) was implemented to test the causality interaction between variables.

The econometric model of Carrión-i-Silvestre et al. (2005) unit root test used for our research to test the long run relationship between insurance penetration and economic growth is the following:

$$
\begin{gathered}
Y_{i t}=\alpha_{i t}+\beta_{i t}+\varepsilon_{i t} \quad i=1,2, \ldots . ., N \text { and } t=1,2, \ldots, T ; \\
\alpha_{i t}=\sum_{k=1}^{m}\left(\theta_{i k} K 1_{i t}\right)+\alpha_{i t}=\sum_{k=1}^{m}\left(\gamma_{i k} K 2_{i t}\right)+u_{i t} ; \\
\beta_{i t}=\sum_{k=1}^{n}\left({ }_{i k} K 1_{i t}\right)+\alpha_{i t}=\sum_{k=1}^{n}\left(\delta_{i k} K 2_{i t}\right)+v_{i t} .
\end{gathered}
$$

$K 1$ and $K 2$ represent the dummy variables and can be described as following:

$$
K 1=\left\{\begin{array}{ll}
1, & t=T_{B}+1 \\
0, & \text { other cases }
\end{array} \quad K 2=\left\{\begin{array}{ll}
1, & t>T_{B}+1 \\
0, & \text { other cases }
\end{array} .\right.\right.
$$

$T_{B}$ is the structural break and enables $\mathrm{m}$ structural breaks in constant term, $\mathrm{n}$ structural break in trend term. The Carrión-i-Silvestre et al. (2005) test permits maximum 5 structural 
breaks. The test detects the structural breaks using the methodology imposed by Bai and Perron (1998), which suggests two different procedures: the modified Schwarz information criterion and the calculation of sequential F statistics. The Carrión-i-Silvestre et al. (2005) unit root test was employed the first one for the model with trend and the second one for the constant model while calculating the number of structural breaks.

Following the methodology proposed by Basher and Westerlund (2009), with multiple structural breaks, we have tested the presence of cointegration between series. The cointegration relationship is analyzed taking cognizance of structural breaks in the periods where there was cross-sectional dependence. The characteristic of this test is that allows breaks in stationary and trend and analyzes the co-integration relationship of the non-stationary series.

The cointegration test statistic is figured out as following:

$$
Z(M)=\frac{1}{N} \sum_{i=1}^{M} \sum_{j=1}^{M_{i}+1} \sum_{t=T_{i j-1}+1}^{T_{i j}}\left(\frac{S_{i t}^{2}}{\left(T_{i j}-T_{i j-1}\right)^{2} \hat{\sigma}_{i}^{2}}\right) .
$$

In Eq. (4), $S_{i t}=\sum_{s=T_{i j-1}+1}^{t} \hat{W}_{i t}$ there is a residual vector from the estimator. $\hat{\sigma}_{i}^{2}$ is a long run variance estimator that rest on $\hat{W}_{i t} . Z(M)$ is calculated using the following equation and simplified by taking cross-sectional averages.

$$
Z(M)=\sum_{t=T_{i j-1}+1}^{T_{i j}}\left(\frac{S_{i t}^{2}}{\left(T_{i j}-T_{i j-1}\right)^{2} \hat{\sigma}_{i}^{2}}\right) \sim N(0,1) .
$$

Taking notice of heterogeneity and cross-sectional dependence, we employed the panel causality test proposed by Dumitrescu and Hurlin (2012).

The standardized test statistic $\left(Z_{T, N}^{H N C}\right)$ for $T, N \rightarrow \infty$ is calculated as follows:

$$
Z_{T, N}^{H N C}=\sqrt{\frac{N}{2 K}}\left(W_{N, T}^{H N C}-K\right) \rightarrow N(0,1)
$$

Furthermore $\tilde{Z}_{T, N}^{H N C}$, for fixed $T$, is calculated as follows:

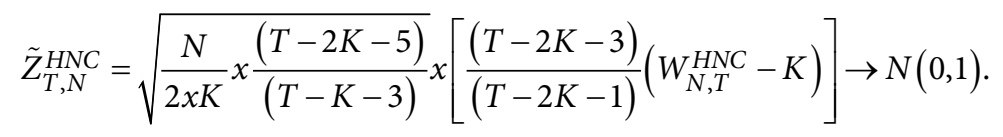

In Eqs (6) and (7), $W_{N, T}^{H N C}=(1 / N) \sum_{i=1}^{N} W_{i, T}$ (Dumitrescu \& Hurlin, 2012).

\section{Empirical analysis}

The first stage of our analysis was the examination of cross-sectional dependence between the series with LM, LM adj. and CD tests. The tests consequences are revealed in Table 3. 
Table 3. Cross-sectional dependence tests (source: own processing)

\begin{tabular}{|c|c|c|}
\hline & Test statistics & Probability value \\
\hline$L M$ & 12.753 & 0.018 \\
\hline$L M_{a d j .}$ & 32.674 & 0.000 \\
\hline$C D$ & 11.907 & 0.002 \\
\hline
\end{tabular}

The results indicate that the null hypothesis expressed as cross-sectional independence is declined because the $\mathrm{p}$ values are less than our predetermined significance level (5\%). Therefore, we admit the availability of cross-sectional dependency between the units.

Secondly, we've tested the null hypothesis of slope homogeneity by employing the test developed by Pesaran and Yamagata (2008) and the findings are revealed in Table 4.

Table 4. Slope of homogeneity test (source: own processing)

\begin{tabular}{|c|c|c|}
\hline & Test stattstics & Probability value \\
\hline$\tilde{\Delta}$ & 12.642 & 0.000 \\
\hline$\tilde{\Delta}_{\text {adj }}$ & 13.569 & 0.000 \\
\hline
\end{tabular}

Since the $\mathrm{p}$ values are lower than our significance level of 0.05 , we declined the null hypothesis in favor of the alternative hypothesis. As a result, the slope coefficients were found to be heterogeneous.

In the next stage, we analyzed the series stationarity using the unit root test indicated by Carrion-i-Silvestre et al. (2005). For this purpose, the null hypothesis of stationarity was tested and the results disclosed that all the series were I(1) (Table 5).

Table 5. Panel unit root test with multiple structural breaks (source: own processing)

\begin{tabular}{|l|c|c|c|c|c|c|}
\hline \multicolumn{1}{|c|}{ Variables } & $P_{T}$ & $M P_{T}$ & $M Z_{\mathrm{a}}$ & $M S B$ & $M Z_{T}$ & Structural break dates \\
\hline GRW & 24.783 & 19.663 & -23.887 & 0.129 & -2.904 & $1999,2008,2009,2012$ \\
\hline D(GRW) & $3.971^{\star}$ & $3.265^{\star}$ & $-14.902^{\star}$ & $0.027^{\star}$ & $-5.042^{\star}$ & - \\
\hline LIFEINS & 19.452 & 17.534 & -25.873 & 0.142 & -3.266 & $1999,2008,2009,2010,2012$ \\
\hline D(LIFEINS) & $3.574^{\star}$ & $4.265^{\star}$ & $-17.483^{\star}$ & $0.047^{\star}$ & $-6.705^{\star}$ & - \\
\hline NON-LIFE & 23.551 & 16.803 & -22.775 & 0.178 & -3.981 & $1999,2008,2009,2011,2012$ \\
\hline D(NON-LIFE) & $3.659^{\star}$ & $5.342^{\star}$ & $-15.042^{\star}$ & $0.031^{\star}$ & $-4.066^{*}$ & - \\
\hline
\end{tabular}

Note: Test critical values were generated through employing bootstrap and rest on 1000 simulation at $5 \%$ significance level. The model allowing structural breaks in both constant and trend was selected.

${ }^{*}$ indicates that it is significant at $5 \%$.

The test successfully detected structural breaks in the series during the global financial crisis and Eurozone sovereign debt crisis. Furthermore, following Basher and Westerlund (2009), we tested for panel cointegration and the results are presented in Table 6. 
Table 6. Panel cointegration test with cross-sectional dependence and multiple structural breaks (source: own processing)

\begin{tabular}{|l|c|c|l|c|l|}
\hline & $\begin{array}{l}\text { LM test } \\
\text { statistic }\end{array}$ & $\begin{array}{c}\text { Asymptotic p value } \\
\text { (disregarding cross- } \\
\text { sectional dependence) }\end{array}$ & Decision & $\begin{array}{c}\text { Bootstrap p value } \\
\text { (regarding cross- } \\
\text { sectional dependence) }\end{array}$ & \multicolumn{1}{|c|}{ Decision } \\
\hline \multicolumn{7}{|c|}{ Test version disregarding structural breaks } \\
\hline Constant & 8.910 & 0.000 & $\begin{array}{l}\text { No cointeg- } \\
\text { ration }\end{array}$ & 0.000 & $\begin{array}{l}\text { No cointeg- } \\
\text { ration }\end{array}$ \\
\hline $\begin{array}{l}\text { Constant }+ \\
\text { trend }\end{array}$ & 7.653 & 0.001 & $\begin{array}{l}\text { No cointeg- } \\
\text { ration }\end{array}$ & 0.000 & $\begin{array}{l}\text { No cointeg- } \\
\text { ration }\end{array}$ \\
\hline \multicolumn{7}{|l|}{ Test version regarding structural breaks } \\
\hline Constant & 11.545 & 0.392 & $\begin{array}{l}\text { Cointeg- } \\
\text { ration }\end{array}$ & 0.382 & $\begin{array}{l}\text { Cointeg- } \\
\text { ration }\end{array}$ \\
\hline $\begin{array}{l}\text { Constant }+ \\
\text { trend }\end{array}$ & 12.884 & 0.277 & $\begin{array}{l}\text { Cointeg- } \\
\text { ration }\end{array}$ & $\begin{array}{l}\text { Cointeg- } \\
\text { ration }\end{array}$ \\
\hline
\end{tabular}

Note: Test critical values were generated through employing bootstrap and rest with 1000 simulation at $5 \%$ significance level.

The findings revealed no cointegration relationship among the series when the cross-sectional dependence was disregarded. However, we took cognizance of the results that established the presence of cross-sectional dependence and structural breaks in the light of pretests' results and study period. Our results demonstrate a significant long run relationship among the series.

The cointegration coefficients have been estimated by Fully Modified OLS (FMOLS) model (Table 7).

Table 7. FMOLS cointegration coefficient estimation

\begin{tabular}{|l|c|c|}
\hline \multicolumn{1}{|c|}{ Countries } & LIFEINS & NON-LIFE \\
\hline Albania & $\mathbf{0 . 0 2 5}$ & $0.042^{\star}$ \\
\hline Bosnia and Herzegovina & $\mathbf{0 . 0 8 1}$ & $0.036^{\star}$ \\
\hline Bulgaria & $\mathbf{0 . 0 0 7}$ & $0.005^{\star}$ \\
\hline Croatia & $\mathbf{0 . 0 0 6}$ & $0.004^{*}$ \\
\hline Czech Republic & $\mathbf{0 . 0 5 3}$ & $0.062^{\star}$ \\
\hline Estonia & $\mathbf{0 . 0 4 6}$ & $0.027^{\star}$ \\
\hline Hungary & $\mathbf{0 . 0 7 4}$ & $0.061^{\star}$ \\
\hline Latvia & $\mathbf{0 . 0 0 3}$ & $0.002^{\star}$ \\
\hline Lithuania & $\mathbf{0 . 0 0 4}$ & $0.005^{\star}$ \\
\hline North Macedonia & $\mathbf{0 . 0 6 1}$ & $0.083^{\star}$ \\
\hline Poland & $\mathbf{0 . 0 5 5}$ & $0.061^{\star}$ \\
\hline Serbia & $\mathbf{0 . 0 5 9}$ & $0.048^{\star}$ \\
\hline Slovak Republic & $\mathbf{0 . 1 0 7}$ & $0.095^{\star}$ \\
\hline Slovenia & $\mathbf{0 . 0 8 6}$ & $0.071^{\star}$ \\
\hline Panel & $\mathbf{0 . 0 5 8}$ & $0.043^{\star}$ \\
\hline
\end{tabular}

Note: The problems of heteroscedasticity and autocorrelation were eliminated through the Newey-West method. ${ }^{*}$ is significant at $5 \%$. 
Our results disclose a positive impact of non-life insurance on economic growth both for the panel and for the individual countries when insurance penetration is used to measure insurance development. In addition, the results indicate the fact that life insurance has no significant effect on the economic growth in both panel and individual countries. The results are in line with those of Dash et al. (2018), which examined 19 Eurozone states for the period of 1980-2014 and found a significant cointegration between insurance market penetration and per capita economic growth for most of the analysed countries.

After analyzing the long-run linkage between variables, Dumitrescu and Hurlin (2012) Granger causality test was employed for causality detection and findings are available in Table 8.

Table 8. Dumitrescu and Hurlin (2012) causality test (source: own processing)

\begin{tabular}{|c|c|c|c|}
\hline Null hypothesis & Test & Test statistics & Probability value \\
\hline \multirow{3}{*}{ GRW $\rightarrow$ LIFEINS } & Whnc & $\mathbf{7 . 8 4 2}$ & $\mathbf{0 . 0 0 0}$ \\
\cline { 2 - 4 } & Zhnc & $\mathbf{6 . 5 9 8}$ & $\mathbf{0 . 0 0 0}$ \\
\cline { 2 - 4 } & Ztild & $\mathbf{6 . 7 2 2}$ & $\mathbf{0 . 0 0 0}$ \\
\hline \multirow{3}{*}{ LIFEINS $\rightarrow$ GRW } & Whnc & 1.432 & 0.287 \\
\cline { 2 - 4 } & Zhnc & 1.055 & 0.195 \\
\cline { 2 - 4 } & Ztild & 1.126 & 0.229 \\
\hline \multirow{3}{*}{ GRW $\rightarrow$ NON-LIFE } & Whnc & $\mathbf{8 . 9 3 2}$ & $\mathbf{0 . 0 0 0}$ \\
\cline { 2 - 4 } & Zhnc & $\mathbf{7 . 0 9 1}$ & $\mathbf{0 . 0 0 1}$ \\
\cline { 2 - 4 } & Ztild & $\mathbf{8 . 2 2 5}$ & 0.002 \\
\hline \multirow{3}{*}{ NON-LIFE $\rightarrow$ GRW } & Whnc & 1.304 & 0.154 \\
\cline { 2 - 4 } & Zhnc & 1.129 & 0.195 \\
\cline { 2 - 4 } & Ztild & 1.503 & \\
\cline { 2 - 4 } & & & \\
\hline
\end{tabular}

The results disclosed a one-way causal linkage from economic growth to both life and non-life sectors, but no significant causal relationship was found from insurance indicators to economic growth.

These findings support previous research that indicated that economic growth has a unidirectional causal influence on life insurance (Guochen \& Wei, 2012; Pradhan et al., 2017; Dash et al., 2018). Our analyses further revealed a uni-causal relationship running from economic growth to non-life insurance markets in all analyzed countries, observations that are consistent with former studies of Guochen and Wei (2012), Pradhan et al. (2017), Dash et al. (2018) and Wanat et al. (2019).

No evidence for a causal relationship between both life and non-life insurance penetration and GRW was found. Similar results were reported by Guochen and Wei (2012), Dash et al. (2018); Wanat et al. (2019) for specific countries/regions. 


\section{Conclusions}

The financial sector is one of the most important sectors of developed economies therefore many studies have analyzed the link between financial development and economic growth. Earlier studies have focused more on exploring the impacts of banks and stock markets on economic growth. However, in recent years, the insurance sector has become more systemically important across countries' economies. In this context, researchers started to raise questions about a causal relationship between insurance development and economic growth.

Financial system is one of the key determinants of economic growth. Substantial evidence demonstrates that the financial sector's development and stability positively influences economic growth. It is no longer accepted as fact that only banking sector and stock market stability are primarily responsible for financial stability, the insurance sector is also considered a significant component of the financial system. Its role of ensuring financial stability is becoming increasingly pronounced.

The insurance sector contributes to financial stability in different ways: firstly, insurers are important investors in the financial market; secondly, it provides stability to insurance policy holders by transferring risk to insurance companies; thirdly, insurers and banks are interconnected; fourthly, the insurance sector is considered a relatively more stable element of financial stability compared to the banking sector and the stock markets.

A unidirectional causal relationship from economic growth to both life and non-life insurance sectors is revealed by our study, these findings supporting the demand-following hypothesis of insurance - economic growth nexus.

Economic growth will lead to a stronger growth of insurance market by increasing the demand for insurance services. Positive changes in real income will drive investors, companies, and population to require diversified financial services that will lead to development of financial institutions in general and insurance services in particular.

Governments must focus on imposing those strategies and policies that can accelerate countries' economic development and foster insurance sector development.

Given the fact that the growth of an economy enhances the demand for insurance products and that the income of insurance companies is directly related to companies and individuals interest in insurance coverage, managers need to develop innovative products and find solutions to accelerate the selling process during the boom period.

Contrary to other results from previous research, we found no relation of causality running from the insurance market (both life and non-life sectors) to economic growth. These differences can arise for various reasons: some of them refer to our methodology, while others refer to our sample countries' characteristics. Firstly, our study used insurance penetration as a proxy variable of insurance sector development, while many other studies used other indicators to measure the level of development. Considering this a limitation of the study, future research may employ different indicators to analyze insurance-growth nexus. Secondly, different methods were used to test the causality direction between the variables; thirdly, other studies analyzed different periods of time.

Taking into consideration the countries' characteristics, there are more possible explanations related to these results: 
Since the fall of communism, the insurance sector in CEE countries has undergone a series of changes, but, after all these years, insurance penetration and insurance coverage have remained below the Western European level. Therefore, it can be expected that this sector's impact on economic growth will be unimportant. Demand for insurance products in the analyzed countries is still low, focusing in particular on compulsory types of insurance.

Insurance companies are one of the largest investors in bonds, stocks, real estate, etc., especially because of their life insurance activities. Since the non-life insurance sector dominates the insurance industry in CEE countries, a less developed life insurance sector will affect the investment portfolio, and countries will face funding deficits.

Possible rises in claims' expenses that reduced insurer investment funds due to increasing numbers of natural catastrophe events that caused significant damages and losses.

Reserves' requirements for insurance companies can be too high.

To stimulate economic growth, the insurance sector must undergo significant changes. Firstly, insurance laws must be revised to change reserves' requirements. They must reflect, with greater accuracy, the risk associated with each particular product. An efficient and solid system of regulation and supervision can help to build companies and individuals confidence in insurance products. Agents, brokers, or other insurance intermediaries' activities must be regulated. Professional standards and specific competences must be required of all insurance agents. Providing the best coverage for customers, using the best strategies to attract potential clients may increase both the number of insured entities and insurance premiums purchased by them.

Secondly, regulatory reforms should be adopted to ensure competitive insurance markets; lack of real competition can lead to higher premiums that affect individuals with low and middle income and small business by losing their risk protection.

Thirdly, governments must encourage the life insurance sector's development. By offering tax incentives to individuals, governments can stimulate the long-term savings associated with life insurance protection. Moreover, insurers can be encouraged to become partners in pension provision.

Growth and development of insurance companies are key objectives of insurance managers and they need to find proper ways to achieve these objectives. Sponsoring educational programs and materials that can help people to better understand the role of insurance policies or the importance of personal savings can have multiple benefits for both insurance companies and individuals. Insurance companies can play a major role in the financial stability of insured clients, but this role must be understood in order to proceed to the final step of buying an insurance policy.

All these measures can stimulate the insurance market in order to have a higher weight in GDP.

Given the vast research on the link between capital market/banking sector development and economic growth, more studies that explore the insurance-growth nexus are required. Banking, insurance, and capital markets sectors are interconnected and each cover different requirements of the economy, therefore more continuous research is required to capture the effect of the insurance sector on economic development since this relationship remains somewhat underemphasized. 
Considering the limited number of countries that have been included in our research, further research is needed that will include a larger sample size and a wide range of country categories (developed countries, developing countries, and least developed countries).

Since there are big differences between insurance market development in developed, developing, and least developed countries, this study provides the core for future research that can compare the role of the insurance sector in promoting economic growth in countries at different stages of development. Insurance sectors in developing countries are facing many challenges related to the liberalization of this sector, regulatory environment, taxation, investments strategies, distribution systems, other local constrains, and therefore the impact of this sector on economic growth can be negatively affected. A strong insurance sector can facilitate growth but is important to understand the factors that can stimulate this sector in countries with different levels of development.

\section{Funding}

The publication of this article was partially supported by the 2020 Development Fund of the Babeş-Bolyai University/Publicarea acestui articol a fost finantata partial prin Fondul de Dezvoltare al Universitatii Babes-Bolyai 2020 and partially by other Fund of the Babeş-Bolyai University.

\section{Author contributions}

All authors have contributed significantly for this research in all phases and sections.

\section{Disclosure statement}

The authors declare that they have no competing financial, professional, or personal interests from other parties.

\section{References}

Abusharbeh, M. T. (2017). The impact of banking sector development on economic growth: Empirical analysis from Palestinian economy. Journal of Emerging Issues in Economics, Finance and Banking (JEIEFB), 6(2), 2306-2316.

Adams, M., Andersson, J., Andersson, L., \& Lindmark, M. (2005). The historical relation between banking, insurance, and economic growth in Sweden: 1830 to 1998 (Working paper).

https://pdfs.semanticscholar.org/55e6/7eaca3876dc32d7820428c5479f27c88fe76.pdf

Adusei, M. (2013). Does finance promote growth in Botswana? Research in Applied Economics, 5(2), 70-81. https://doi.org/10.5296/rae.v5i2.3821

Ahmed, J., \& Bashir, M. F. (2016). An empirical investigation of banking sector development and economic growth in a panel of Selected SAARC countries. Theoretical and Applied Economics, 23(2), $65-72$.

Alhassan, A. L., \& Biekpe, N. (2016). Insurance market development and economic growth: Exploring causality in 8 selected African countries. International Journal of Social Economics, 43(3), 321-339. https://doi.org/10.1108/IJSE-09-2014-0182 
Ang, J. A., \& McKibbin, W. J. (2007). Financial liberalization, financial sector development and growth: Evidence from Malaysia. Journal of Development Economics, 84(1), 215-233. https://doi.org/10.1016/j.jdeveco.2006.11.006

Anton, S. G. (2019). Leverage and firm growth: An empirical investigation of gazelles from emerging Europe. International Entrepreneurship and Management Journal, 15, 209-232. https://doi.org/10.1007/s11365-018-0524-5

Arena, M. (2008). Does insurance market activity promote economic growth? A crosscountry study for industrialized and developing countries. Journal of Risk and Insurance, 75(4), 921-946. https://doi.org/10.1111/j.1539-6975.2008.00291.x

Bagehot, W. (1873). Lombard street: A description of the money market. History of economic thought books. In McMaster University archive for the history of economic thought.

Bai, J., \& Perron, P. (1998). Estimating and testing linear models with multiple structural changes. Econometrica, 66(1), 47-78. https://doi.org/10.2307/2998540

Balcilar, M., Gupta, R., Lee, C. C., \& Olasehinde-Williams, G. (2019). Insurance-growth nexus in Africa. The Geneva Papers on Risk and Insurance - Issues and Practice, 45, 335-360. https://doi.org/10.1057/s41288-019-00145-7

Basher, A. B., \& Westerlund, J. (2009). Panel cointegration and the monetary exchange rate model. Economic Modelling, 26(2), 506-513. https://doi.org/10.1016/j.econmod.2008.10.006

Bayar, Y., Borozan, D., \& Gavriletea, M. D. (2020). Banking sector stability and economic growth in post-transition European Union countries. International Journal of Finance \& Economics, 1-13. https://doi.org/10.1002/ijfe.1829

Bayar, Y., \& Gavriletea, D. M. (2018). Financial inclusion and economic growth: Evidence from transition economies of European Union. International Journal of Finance and Economics, 18(2), 95-100. https://doi.org/10.18374/JIFE-18-2.9

Beenstock, M., Dickinson, G., \& Khajuria, S. (1988). The relationship between property-liability insurance and income: An international analysis. Journal of Risk and Insurance, 55(2), 259-272. https://doi.org/10.2307/253327

Beenstock, M., Dickinson, G., \& Khajuria, S. (1986). The determination of life premiums: An international crosssection analysis 1970-1981. Insurance, Mathematics and Economics, 5(4), 261-270. https://doi.org/10.1016/0167-6687(86)90020-X

Bittencourt, M. (2012). Financial development and economic growth in Latin America: Is Schumpeter right? Journal of Policy Modeling, 34(3), 341-355. https://doi.org/10.1016/j.jpolmod.2012.01.012

Breusch, T. S., \& Pagan, A. R. (1980). The Lagrange multiplier test and its applications to model specification in econometrics. Review of Economic Studies, 47(1), 239-253. https://doi.org/10.2307/2297111

Caporale, G. M., Rault, C., Sova, A. D., \& Sova, R. (2015). Financial development and economic growth: Evidence from $10 \mathrm{New}$ European Union members. International Journal of Finance and Economics, 20(1), 48-60.

Carrión-i-Silvestre, J. L., del Barrio-Castro, T., \& López-Bazo, E. (2005). Breaking the panels: An application to the GDP per capita. Econometrics Journal, 8(2), 159-175. https://doi.org/10.1111/j.1368-423X.2005.00158.x

Christopoulos, D. K., \& Tsionas, E. G. (2004). Financial development and economic growth: Evidence from panel unit root and cointegration tests. Journal of Development Economics, 73(1), 55-74. https://doi.org/10.1016/j.jdeveco.2003.03.002

Cristea, M., Marcu, N., \& Cârstina, S. (2014). The relationship between insurance and economic growth in Romania compared to the main results in Europe - A theoretical and empirical analysis. Procedia Economics and Finance, 8(14), 226-235. https://doi.org/10.1016/S2212-5671(14)00085-9

Ćurak, M., Lončar, S., \& Poposki, K. (2009). Insurance sector development and economic growth in transition countries. International Research Journal of Finance and Economics, 34, 29-41. 
Dash, S., Pradhan, R. P., Maradana, R. P., Gaurav, K., Zaki, D. B., \& Jayakumar, M. (2018). Insurance market penetration and economic growth in Eurozone countries: Time series evidence on causality. Future Business Journal, 4(1), 50-67. https://doi.org/10.1016/j.fbj.2017.11.005

Demirci, Ş. D., \& Zeren, F. (2017). Insurance premium and economic growth: Evidence from OECD countries. İşletme Bilimi Dergisi, 5(1), 1-11. https://doi.org/10.22139/jobs.286819

Din, S. M. U., Abu-bakar, A., \& Regupathi, A. (2017). Does insurance promotes economic growth: A comparative study of developed and emerging/developing economies. Cogent Economics \& Finance, 5(1), 1390029. https://doi.org/10.1080/23322039.2017.1390029

Dumitrescu, E., \& Hurlin, C. (2012). Testing for Granger non-causality in heterogeneous panels. Economic Modelling, 29(4), 1450-1460. https://doi.org/10.1016/j.econmod.2012.02.014

Durusu-Ciftci, D., Ispir, M. S., \& Yetkiner, H. (2017). Financial development and economic growth: Some theory and more evidence. Journal of Policy Modeling, 39(2), 290-306. https://doi.org/10.1016/j.jpolmod.2016.08.001

Guochen, P., \& Wei, S. C. (2012, July 18-21). The relationship between insurance development and economic growth: A cross-region study for China [Conference presentation]. 2012 China International Conference on Insurance and Risk Management, Qingdao. http://www.ccirm.org/conference/2012/uploadfiles/A/II-A/4-PANGuochen_Pan_full_text_.pdf

Gurley, J. G. \& Shaw, E. S. (1955). Financial aspects of economic development. American Economic Review, 45(4), 515-538. http://www.jstor.org/stable/1811632

Guru, B. K., \& Yadav, I. S. (2019). Financial development and economic growth: Panel evidence from BRICS. Journal of Economics, Finance and Administrative Science, 24(47), 113-126. https://doi.org/10.1108/JEFAS-12-2017-0125

Haiss, P., \& Sumegi, K. (2008). The relationship between insurance and economic growth: Review and agenda. The IcFai Journal of Risk and Insurance, 5(2), 32-56.

Han, L., Li, D., Moshirian, F., \& Tian, Y. (2010). Insurance development and economic growth. Geneva Papers on Risk Insurance - Issues and Practice, 35(2), 183-199. https://doi.org/10.1057/gpp.2010.4

Hicks, J. R. (1969). A theory of economic history. Oxford University Press.

International Association of Insurance Supervisors. (2017). Measuring insurance development: Beyond the insurance penetration rate (Report of the $21^{\text {st }} \mathrm{A} 2 \mathrm{ii}$ - IAIS Consultation Call). https://a2ii.org/sites/default/files/reports/21._consultation_call_engl_web_0.pdf

Jayakumar, M., Pradhan, R. P., Dash, S., Maradana, R. P., \& Gaurav, K. (2018). Banking competition, banking stability, and economic growth: Are feedback effects at work? Journal of Economics and Business, 96, 15-41. https://doi.org/10.1016/j.jeconbus.2017.12.004

Kessler, D., Montchalin, A. de, \& Thimann, Ch. (2016). Insurance and economic development: Growth, stabilization and distribution (Paper no. 46). International Labour Organization (ILO). https://www.ilo.org/wcmsp5/groups/public/---ed_emp/documents/publication/wcms_613701.pdf

Kugler, M., \& Ofoghi, R. (2005, September 3). Does insurance promote economic growth? Evidence from the UK [Conference presentation]. Money Macro and Finance (MMF) Research Group Conference, Money Macro and Finance Research Group.

Ledhem, M. A., \& Mekidiche, M. (2020). Economic growth and financial performance of Islamic banks: A CAMELS approach. Islamic Economic Studies, 28(1), 47-62.

Levine, R., \& Zervos, S. (1998). Stock markets, banks, and economic growth. American Economic Review, 88(3), 537-558.

https://econpapers.repec.org/article/aeaaecrev/v_3a88_3ay_3a1998_3ai_3a3_3ap_3a537-58.htm

Liang, H.-Y., \& Reichert, A. (2006). The relationship between economic growth and banking sector development. Banks and Bank Systems, 2(1), 19-35. https://www.businessperspectives.org/images/ pdf/applications/publishing/templates/article/assets/1540/BBS_en_2006_02_Liang.pdf 
Liang, H.-Y., \& Reichert, A. (2012). The impact of banks and non-bank financial institutions on economic growth. The Service Industries Journal, 32(5), 699-717. https://doi.org/10.1080/02642069.2010.529437

Mmolainyane, K., \& Ahmed, A. D. (2015). The impact of financial integration in Botswana. Journal of Policy Modelling, 37(5), 852-874. https://doi.org/10.1016/j.jpolmod.2015.03.015

Munich RE. (2018). Insurance market outlook for 2018/2019. https://www.munichre.com/topics-online/ en/economy/insurance-markets/outlook-2018-2019.html

Njegomir, V., \& Stojić, D. (2010). Does insurance promote economic growth: The evidence from ExYugoslavia region. Ekonomska Misao I Praksa, 1, 31-48. https://hrcak.srce.hr/54655

Outreville, F. J. (2013). The relationship between insurance and economic development: 85 empirical papers for a review of the literature. Risk Management and Insurance Review, 16(1), 71-122. https://doi.org/10.1111/j.1540-6296.2012.01219.x

Outreville, J. F. (1990). The economic significance of insurance markets in developing countries. Journal of Risk and Insurance, 57(3), 487-498. https://doi.org/10.2307/252844

Peleckienè, V., Peleckis, K., Dudzevičiūte, G., \& Peleckis, K. K. (2019). The relationship between insurance and economic growth: Evidence from the European Union countries. Economic ResearchEkonomska Istraživanja, 32(1), 1138-1151. https://doi.org/10.1080/1331677X.2019.1588765

Pesaran, M. H. (2004). General diagnostic tests for cross section dependence in panels (Working Paper, CWPE 0435). University of Cambridge.

Pesaran, M. H., \& Yamagata, T. (2008). Testing slope homogeneity in large panels. Journal of Econometrics, 142(1), 50-93. https://doi.org/10.1016/j.jeconom.2007.05.010

Pesaran, M. H., Ullah, A., \& Yamagata, T. (2008). A bias-adjusted LM test of error cross-section independence. Econometrics Journal, 11(1), 105-127. https://doi.org/10.1111/j.1368-423X.2007.00227.x

Petros, J. (2012). The effect of the stock exchange on economic growth: A case of the Zimbabwe stock exchange. Research in Business and Economics Journal, 6, 1-17.

http://www.aabri.com/manuscripts/111088.pdf

Pradhan, R. P., Arvin, M. B., Hall, J. H., \& Nair, M. (2016). Innovation, financial development and economic growth in Eurozone countries. Applied Economics Letters, 23(16), 1141-1144. https://doi.org/10.1080/13504851.2016.1139668

Pradhan, R. P., Dash, S., Jayakumar, M., Maradana, R., Zaki, D., \& Chatterjee, D. (2017). Insurance market density and economic growth in Eurozone countries: The granger causality approach. Financial Innovation, 1(3), 1-24. https://doi.org/10.1186/s40854-017-0065-x

Ram, R. (1999). Financial development and economic growth: Additional evidence. Journal of Development Studies, 35(4), 164-174. https://doi.org/10.1080/00220389908422585

Raza, S. A., \& Jawaid, S. T. (2014). Foreign capital inflows, economic growth and stock market capitalization in Asian countries: An ARDL bound testing approach. Quality \& Quantity, 48(1), 375-385. https://doi.org/10.1007/s11135-012-9774-4

Ricci, O. (2014). Corporate Governance in the European insurance industry. In Roma Tre Business and Finance Collection. Palgrave Macmillan UK. https://doi.org/10.1057/9781137376046

Rioja, F., \& Valev, N. (2004). Does one size fit all? A reexamination of the finance and growth relationship. Journal of Development Economics, 74(2), 429-447.

https://doi.org/10.1016/j.jdeveco.2003.06.006

Schumpeter, J. A. (1911). A theory of economic development. Harvard University Press.

Schumpeter, J. A. (1934). Theorie der Wirtschaftlichen Entwickiung [The theory of economic development] (Redvers Opie, Trans.). Dunker \& Humblot (original work published 1912).

Skipper, H. D. (2001). Insurance in the general agreement on trade in services. American Enterprise Institute Press. 
Su, C.-W., Chang, H.-L., \& Pan, G. (2013). Tests for causality between insurance development and economic growth using asymptotic and panel bootstrap distributions. Economic Computation and Economic Cybernetics Studies and Research, 47(3), 111-131. http://www.ecocyb.ase.ro/nr.3.pdf/Chi-Wei\%20Su.pdf

Sulemana, M., \& Dramani, J. B. (2020) Effect of financial sector development and institutions on economic growth in SSA. Does the peculiarities of regional blocs matter? Journal of Sustainable Finance \& Investment. https://doi.org/10.1080/20430795.2020.1837500

Tongurai, J., \& Vithessonthi, C. (2018). The impact of the banking sector on economic structure and growth. International Review of Financial Analysis, 56, 193-207. https://doi.org/10.1016/j.irfa.2018.01.002

Uddin, G. S., Sjö, B., \& Shahbaz, M. (2013). The causal nexus between financial development and economic growth in Kenya. Economic Modelling, 35, 701-707. https://doi.org/10.1016/j.econmod.2013.08.031

United Nations. (1964). Proceedings of the United Nations Conference on Trade and Development (UNCTAD), Vol. I: Final act and report (p. 55, annex A.IV.23). https://unctad.org/system/files/official-document/econf46d141vol1_en.pdf

United Nations. (2007). Trade and development aspects of insurance services and regulatory frameworks. United Nations Conference on Trade and Development (UNCTAD). https://unctad.org/en/Docs/ditctncd20074_en.pdf

Wanat, S., Papiez, M., \& Smiech, S. (2019). Insurance market development and economic growth in transition countries: Some new evidence based on the bootstrap panel granger causality test. Argumenta Oeconomica, 1(42), 213-233. https://doi.org/10.15611/aoe.2019.1.09

Ward, D., \& Zurbruegg, R. (2000). Does insurance promote economic growth? Evidence from OECD countries. The Journal of Risk and Insurance, 67(4), 489-506. https://doi.org/10.2307/253847

World Bank. (2019a). GDP growth (annual \%). https://data.worldbank.org/indicator/NY.GDP.MKTP.KD.ZG (10.03.2019)

World Bank. (2019b). Life insurance premium volume to GDP (\%) https://www.worldbank.org/en/publication/gfdr/data/global-financial-development-database

World Bank. (2019c). Non-life insurance premium volume to GDP (\%). https://www.worldbank.org/en/publication/gfdr/data/global-financial-development-database

Zortuk, M., \& Çelik, Y. (2014). The relationship between bank loans and economic growth in Turkey: 1995-2010. Alphanumeric Journal, 2(2), 52-60. https://doi.org/10.17093/aj.2014.2.2.5000084656 